\title{
Analysis on the Layout Evolution and External Space Characteristics of the Red Gate Palace in Taishan
}

\author{
Xue Wei* \\ Zibo Vocational Institute, Zibo 255314, Shandong Province, China \\ *Corresponding author: Xue Wei, WeiXue921215@163.com
}

\begin{abstract}
This article organizes and analyzes the historical evolution as well as the current situation of the Red Gate Palace, and probes into the artistic characteristics of the exterior space of the building. The conclusions are as follows: Relying on the unique forest environment of Mount Tai, the Red Gate Palace forms an impression of negative yin-yang where it is overlooking waters and with hills at the back. The guiding space comprising of the climbing route, the archway, and the Feiyun Pavilion which is built on the crossroad plays the role of guidance and suggestion; forming a complete spatial sequence with rhythm. The courtyard space which constitutes the east and west courtyards, in addition to the Little Taishan Temple is reasonable and ingenious in layout along with rich as well as well-proportioned spaces, and pleasant in scale.
\end{abstract}

Keywords: Red Gate Palace in Taishan; Guiding space; Courtyard space; Space characteristic

Publication date: July 2021; Online publication: July 31, 2021

\section{Introduction}

It is impossible to verify when the Red Gate Palace was founded. It has been repaired repeatedly since the Ming and Qing Dynasties. It is an important part of Taishan Ancient Architecture Group which is the key cultural relics protection unit of the state. Its architecture, tablet inscriptions, and memorial archways in the courtyard are of great historical value for the cultural study of ancient Buddhism, Taoism, as well as extended folk beliefs. As a religious building in a garden, the organic whole formed by the building, courtyard, and surrounding environment has a unique spatial layout.

\section{Summary of the current situation}

The Red Gate Palace is located at the north end of Hongmen Road, northwest of Wangmu Pool, with Guan Yu Temple at its south, the Middle Stream at its east, and Dacang Ridge at its west (Figure 1.). Covering an area of 2,528.2 square meters, it comprises of Yuanjun Hall in the west courtyard (including Little Taishan Temple), Maitreya Hall in the east courtyard, and the Feiyun Pavilion which is built across the climbing route connecting the east and the west courtyards.

The west courtyard of the Red Gate Palace consists of the main gate, Yuanjun Hall, Qiezhi Pavilion, the Heyun Pavilion, and the Floral-pendant Gate (Figure 2.). The main gate is the stone memorial archway with an architrave that is titled, "Red Gate Palace," and four words under it, "Yan Zhan Chu Bu." The main entrance has a side entrance to the south and another to the north. The main sections of the west courtyard are the Yuanjun Hall which is comprised of a lifting frame with four pillars and five beams, the west side hall which is the Heyun pavilion, the south hall which is Qiezhi Pavilion, and further down, the incense pool. The Floral-pendant Gate is located between Yuanjun Hall and Heyun Pavilion, which leads to the 
northern Zen house and Little Taishan Temple. The Zen house comprises of the main hall and two side halls. To its northwest is the Little Taishan Temple with three columns in its hall.

The east courtyard comprises of the gate, Maitreya Hall, Gengyi Pavilion, South Hall, and other buildings (Figure 2.). The gate is westward with a stiff peak made up of four-column canopy. The main building, Maitreya Hall has three broad-faced buildings with nine hard mountain purlins at its front corridor. Gengyi Pavilion, which is a hall-style building is the east side hall of the east courtyard. The South Hall is located at the south of the courtyard, and at the south of the hall is a small courtyard.

Feiyun Pavilion, which connects the east and west courtyards, is a tunnel-like passageway building, which is divided into upper and lower layers. The lower layer is an arched portal whereas the upper part has three main halls. The east and west courtyards as well as the Feiyun Pavilion form a group of semienclosed concave space (Figure 2.).

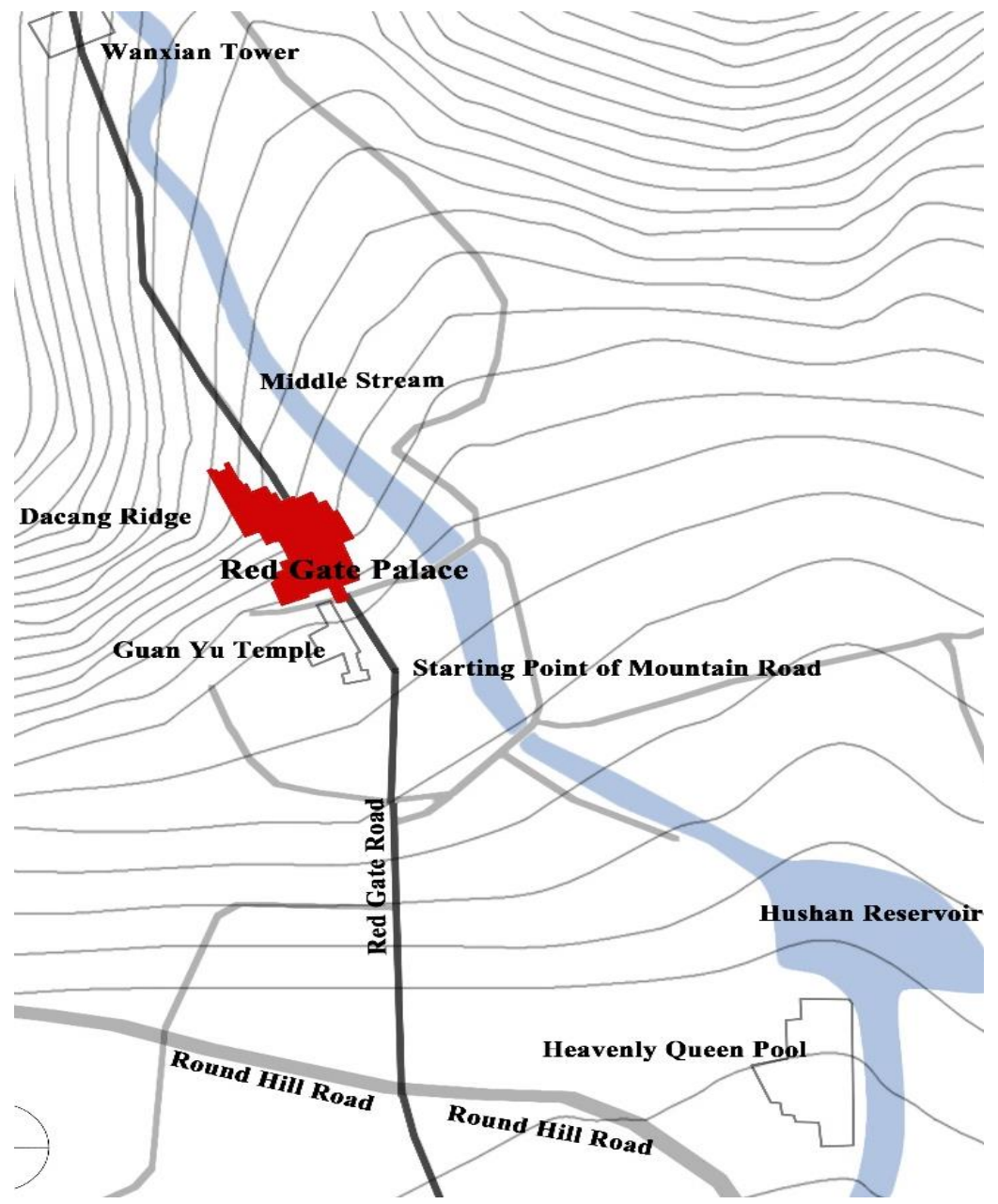

Figure 1. Location map of Red Gate Palace

\section{Historical evolution}

It is not known when the Red Gate Palace was founded. According to historical records, in the sixth year of Tianqi in the Ming Dynasty (1626), there was an extension construction ${ }^{[1]}$. In the Wanli Period of the Ming Dynasty (1563-1620), the Gengyi Pavilion (Figure 3.) was used for changing clothes when mountaineering ${ }^{[2]}$. In the Qing Dynasty, Feiyun Pavilion was renamed as Guanyin Pavilion, and the Gengyi Pavilion was renamed as Maitreya Hall. Yuanjun Temple, Red Gate Memorial Archway, and Heyun Pavilion were also built there ${ }^{[3-4]}$ (Figure 4.). The Little Taishan Temple in the north of the palace can be seen in many documents during the period of the Republic of China ${ }^{[5]}$ (Figure 5.). After the establishment 
of the Republic of China, it has been repaired many times. The two integrated, and finally formed the current pattern.

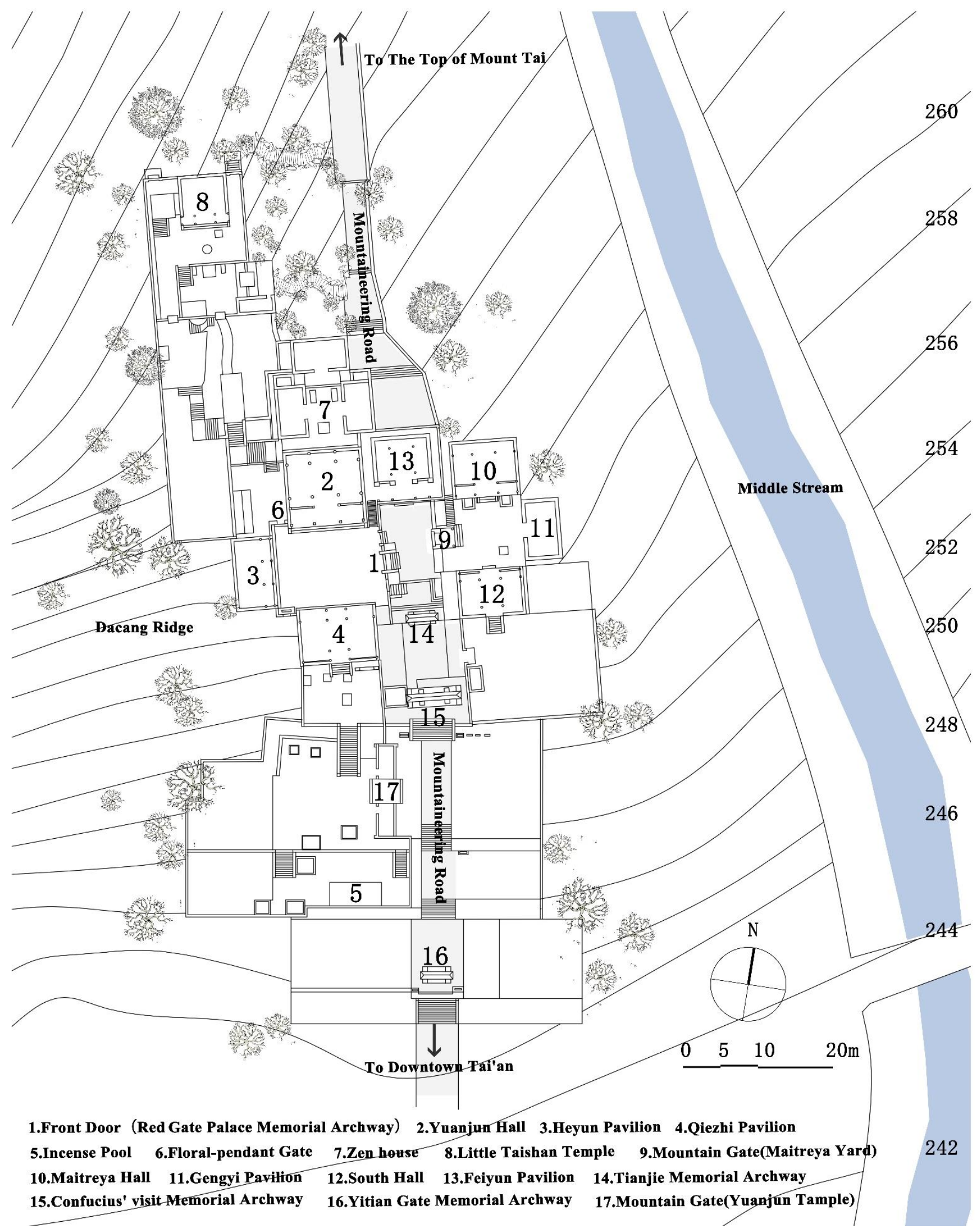

Figure 2. General layout of the Red Gate Palace 


\section{Site selection and spatial layout}

\subsection{Site selection}

Located at the foot of Mount Tai, the Red Gate Palace is adjacent to the towering Dacang Ridge to the west and the winding Middle Stream to the east, forming an impression of negative yin-yang where it is overlooking waters and with hills at the back. Its surrounding vegetation is luxuriant, with mountains and waters embracing it; being naturally pleasurable.

\subsection{Entire allocation}

As a group of religious buildings, the Red Gate Palace consists of two parts: the guiding space and the courtyard space ${ }^{[6]}$ (Figure 6.). Influenced by the layout of traditional folk houses and temples in the north, the Red Gate Palace is spread out vertically and horizontally in the form of multiple three-hedron courtyards and quadrangle courtyards while the main halls and side halls for the worship of statues are arranged on the axis. Due to its mountainous location, it is different from the strict axial symmetry layout pattern of flat temples. The whole courtyard of the Red Gate Palace emphasizes more on the integration and construction of mountains which reflect the ecological view of Taoism where, "Taoism follows nature." However, some of them are still symmetrical, reflecting the idea of "the notability is in the center." For example, the main buildings of the eastern and western houses, the Maitreya Hall, and Yuanjun Hall are all arranged symmetrically with the climbing route as the central axis (Figure 7.) ${ }^{[7-8]}$.

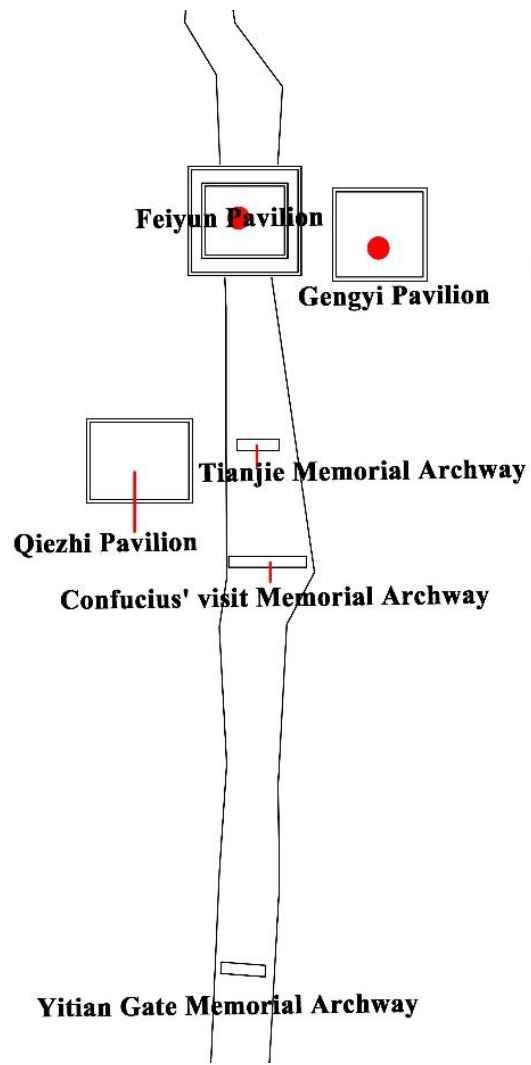

Figure 3.

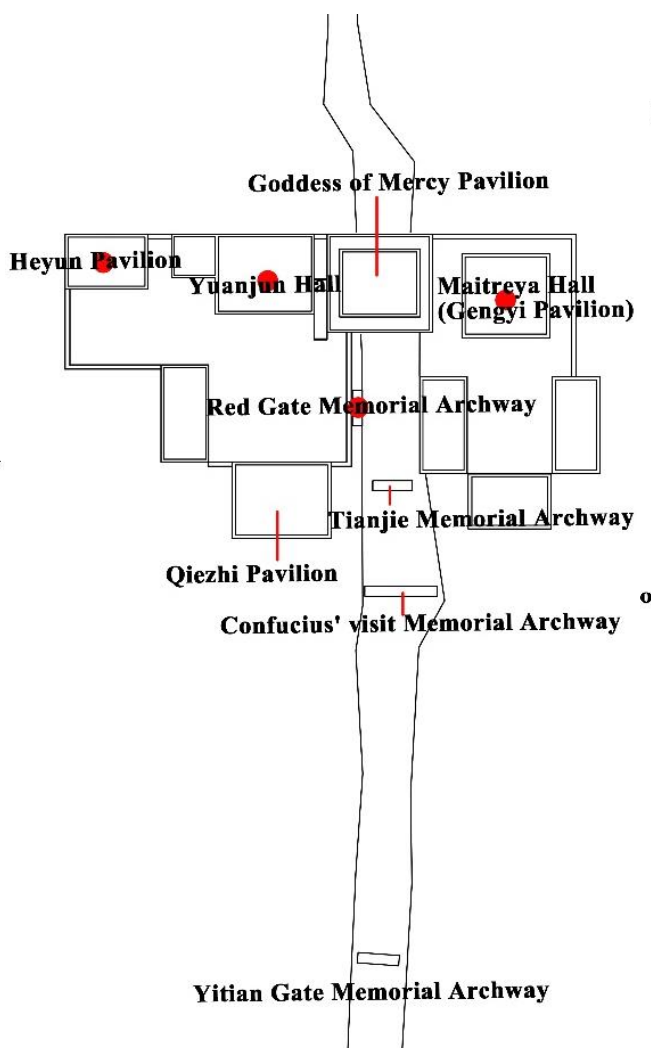

Figure 4.

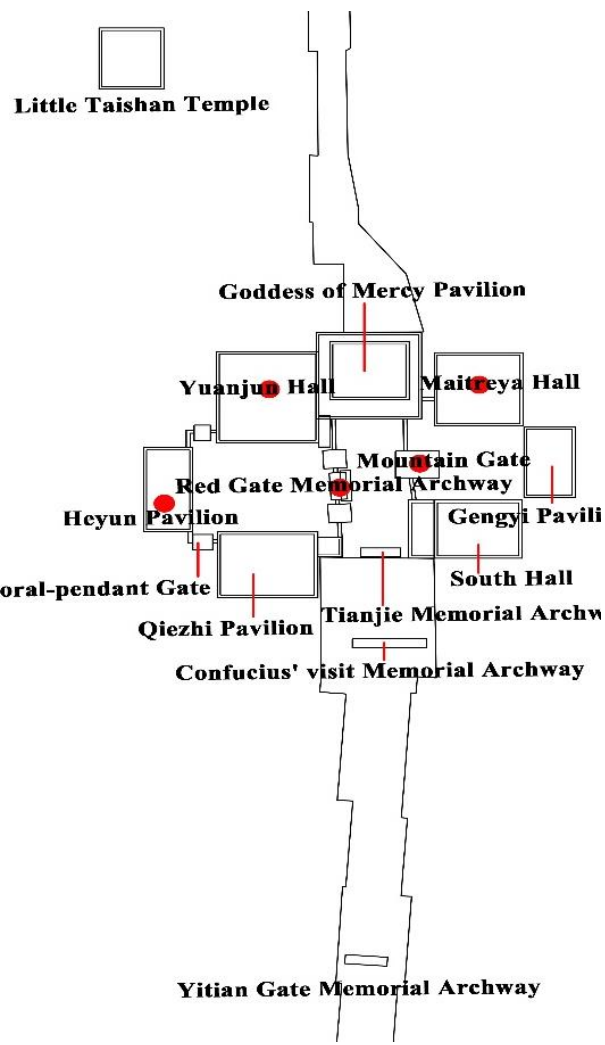

Figure 5.

(1) Figure 3. Layout plan of the Red Gate Palace during Wanli Period of Ming Dynasty

(2) Figure 4. Layout plan of the Red Gate Palace during Qianlong Period of Qing Dynasty

(3) Figure 5. Layout plan of the Red Gate Palace in the early years of the Republic of China 


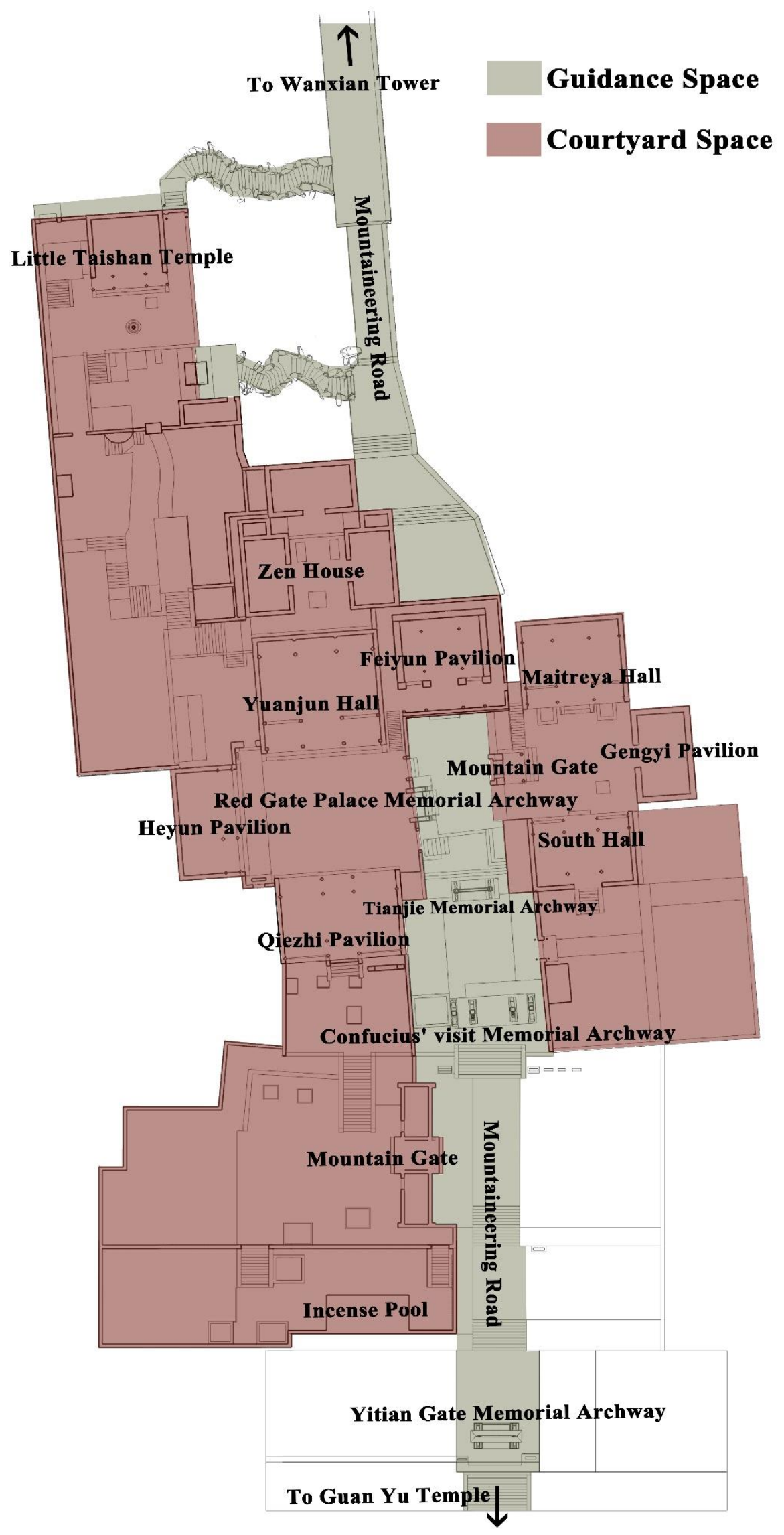

Figure 6. Spatial layout of the Red Gate Palace 


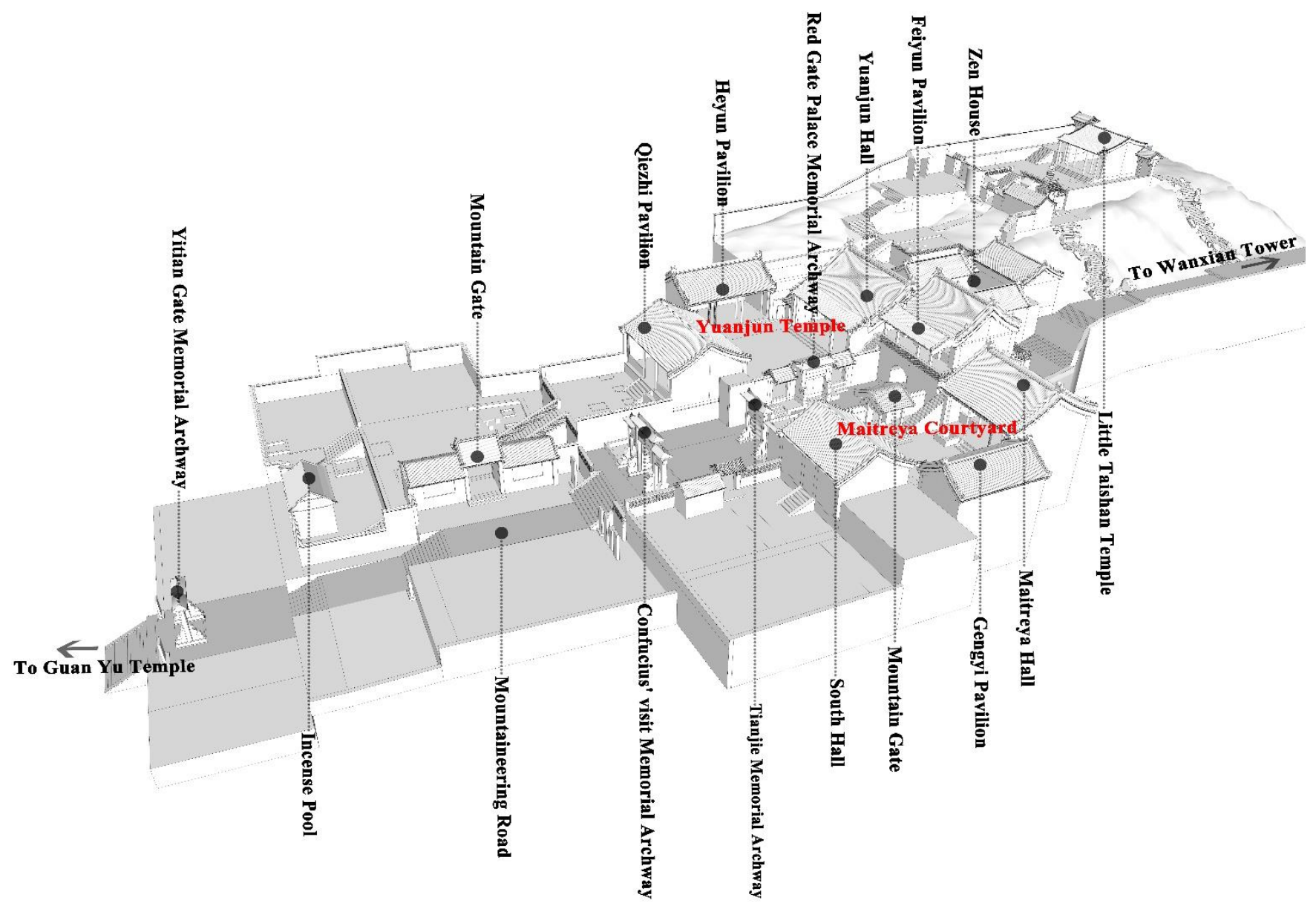

Figure 7. Aerial view of the Red Gate Palace

\subsection{Space function and composition}

\subsubsection{Function and composition of the guiding space}

The pilgrimage activities in Red Gate Palace do not begin when the pilgrims enter the courtyard, but gradually unfold in the outer space of the palace ${ }^{[9]}$. From the steps in front of Yitian Gate to the climbing route in front of the Red Gate Palace, while meeting the basic traffic and sacrificial functions, the space for "pilgrimage" is formed which becomes the beginning of the palace temple sequence. On the one hand, it connects the urban environment with the palace in a natural mountain forest which stimulates the religious emotions in pilgrims. On the other hand, its sacred and solemn atmosphere in addition to climbing its stone steps make pilgrims feel that they are "far from the world." In combination, the outer wall of the building, archway, steles, plants, natural rocks, and the Feiyun Pavilion which is built across the road constitute the guiding space of the Red Gate Palace (Figure 8.). The inscriptions on the archway, steles, and the walls of the building expand the spatial information perceived by the pilgrims across the dimensions of time and space.

\subsubsection{Function and composition of the courtyard space}

The courtyard space mainly meets the religious sacrificial function. Decorated with flowers, trees, and furnishings, it is enclosed by the main building, the wall, as well as the mountain gate. According to its function, it can be divided into sacrificial spaces, working spaces, and sightseeing spaces whereas based on its spatial nature, it can be divided into transitional space, core space, and subsequent space ${ }^{[6]}$ (Figure 9.).

The core space is the main sacrificial space which comprises of Yuanjun Hall and its side hall in the west courtyard, as well as Maitreya Hall in the east courtyard with the Feiyun Pavilion connecting them. 
The architectural grade and volume are unparalleled in the whole palace. The first courtyard of the west courtyard is a transitional space with multi-layered terraces and pine trees planted in its courtyard which create a solemn and sacred atmosphere, guiding visitors and pilgrims into the main hall. The Zen house and the Little Taishan Temple constitute the subsequent space which is the continuation and supplement of the core space that enriches the spatial level and plays the role of "turning" in order to avoid the abrupt end of the spatial sequence after the climax in eliminating the sense of awkwardness.

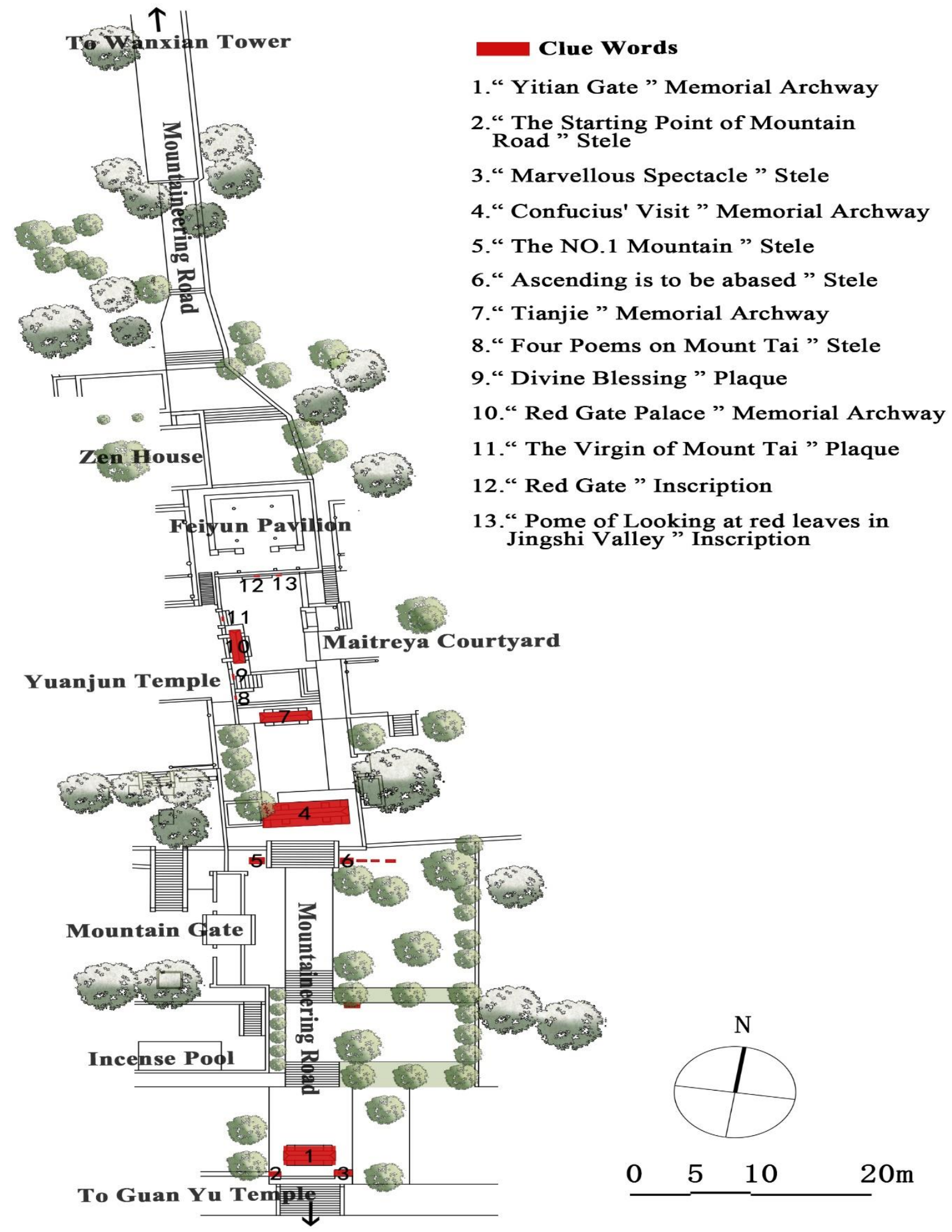

Figure 8. Plan of guiding space 

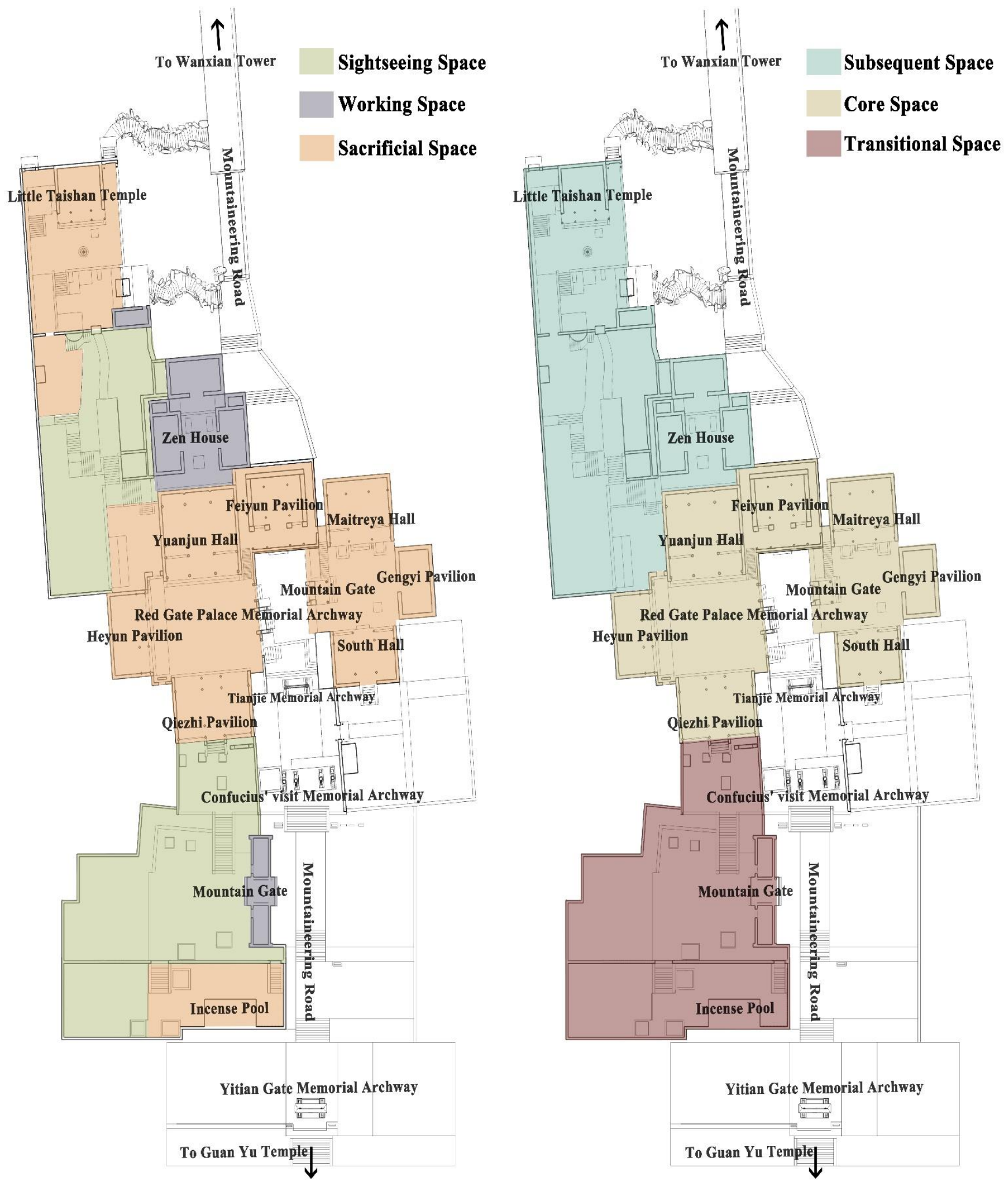

Figure 9. Classification map of the courtyard space of Red Gate Palace

\subsection{Spatial scale analysis of the courtyard}

Restricted by the rugged mountains, the architectural volume of the Red Gate Palace is not very grand, and the absolute size of the courtyards is very limited, but it still constructs rich space (Table 1.). 
Table 1. Scales of courtyard space

\begin{tabular}{|c|c|c|c|c|c|c|c|}
\hline $\begin{array}{l}\text { Types of } \\
\text { courtyard } \\
\text { space }\end{array}$ & $\begin{array}{l}\text { Name of } \\
\text { courtyard }\end{array}$ & Length (m) & Width (m) & $\begin{array}{l}\text { Aspect } \\
\text { ratio }\end{array}$ & $\begin{array}{l}\text { Area } \\
\left(\mathbf{m}^{2}\right)\end{array}$ & $\begin{array}{l}\text { Plane } \\
\text { form }\end{array}$ & Plane icon \\
\hline \multirow{3}{*}{$\begin{array}{l}\text { Transitional } \\
\text { space }\end{array}$} & $\begin{array}{l}\text { Incense } \\
\text { Pool } \\
\text { Courtyard }\end{array}$ & 7.50 & 30.23 & 0.29 & 227.30 & Rectangle & \\
\hline & $\begin{array}{l}\text { Mountain } \\
\text { Gate } \\
\text { Courtyard }\end{array}$ & 17.22 & 25.76 & 0.71 & 391.11 & Rectangle & \\
\hline & $\begin{array}{l}\text { Feiyun } \\
\text { Pavilion }\end{array}$ & 9.00 & 10.58 & 0.85 & 90.71 & Square & \\
\hline \multirow{3}{*}{ Core space } & $\begin{array}{l}\text { Yuanjun } \\
\text { Hall }\end{array}$ & 10.46 & 14.48 & 0.72 & 154.36 & Rectangle & \\
\hline & $\begin{array}{l}\text { Feiyun } \\
\text { Pavilion }\end{array}$ & 9.56 & 10.53 & 0.91 & 48.17 & “回” shape & \\
\hline & $\begin{array}{l}\text { Maitreya } \\
\text { Hall }\end{array}$ & 8.90 & 11.50 & 0.77 & 96.91 & “凹” shape & \\
\hline \multirow{3}{*}{$\begin{array}{l}\text { Subsequent } \\
\text { space }\end{array}$} & Zen House & 10.48 & 4.82 & 2.17 & 64.42 & "工” shape & \\
\hline & $\begin{array}{l}\text { Little } \\
\text { Taishan } \\
\text { Temple }\end{array}$ & 19.28 & 12.51 & 1.54 & 193.93 & “凹” shape & \\
\hline & $\begin{array}{l}\text { West side } \\
\text { of } \quad \text { Zen } \\
\text { House }\end{array}$ & / & l & / & 531.14 & Rectangle & \\
\hline
\end{tabular}

Different from ordinary buildings, the core space of the Red Gate Palace is small in size and limited in space, presenting a special “回” or “凹” shape while the transitional space and subsequent space have relatively wide vision, and their plane forms are mostly square in nature. The length-to-width ratio of each courtyard in the transitional space and the core space is less than 1, which gives people a sense of isolation whereas the length-to-width ratio of the subsequent space courtyard is greater than 1, which has a profound artistic conception. The courtyard of Little Taishan Temple has a length-to-width ratio between 1 and 2 with a compact space and a strong sense of balance ${ }^{[8,10]}$.

\section{Spatial features}

\subsection{Features of the guiding space}

\subsubsection{Guidance and suggestion}

The building walls on both sides of the middle road enhance the sense of longitudinal extension and form a long, narrow space with strong guiding propensity. The gradually rising steps and building walls also make people feel the change in different positions ${ }^{[11]}$, thus effectively playing the role of guidance and suggestion (Figure 10.). 


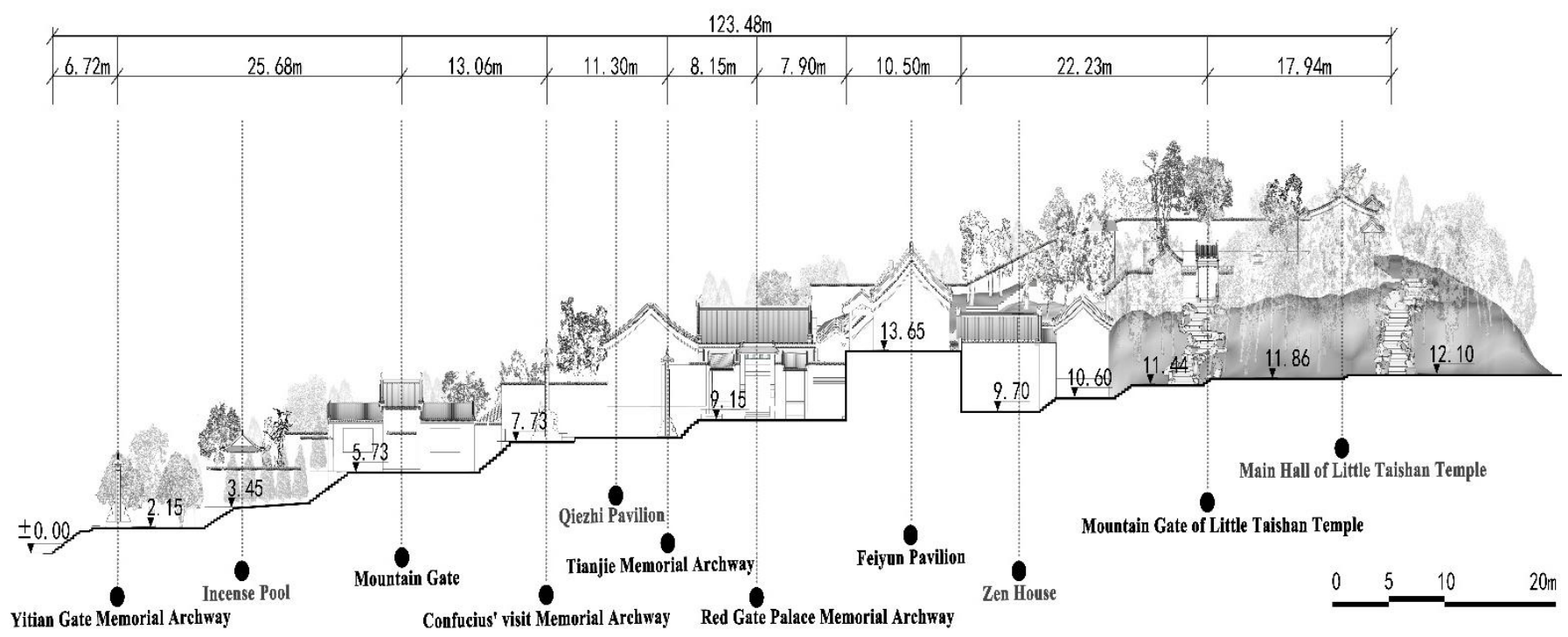

Figure 10. Sections of guiding space

\subsubsection{Rhythm and rhyme}

A complete rhythm is formed by the elevation of the terrain and the arrangement of the four groups of archways. The distance, volume, shape, and structure of each archway as well as the difference in content exude a certain rhythm. Combining the ups and downs as well as the opening and closing of the level, time, space, and landscape are all coordinated so that the pilgrims and visitors have an experience similar to, "It is like a range when you look at the mountain from the front, but it is like a peak when you look at it sideways" (Figure 10.).

\subsubsection{Complete spatial sequence}

As a space independent of the palace courtyard, the guiding space itself also forms a complete spatial sequence. When the visitors' sight is focused at the center of the road, the memorial archway and buildings built across the road are connected as the focal point of the sight. Yitian Gate square has a wider view which is the initial stage of the spatial sequence. As the tour moves on, the buildings on both sides gradually appear in the line of sight. When arriving at the Confucius' visits and Tianjie Memorial Archway, the space is slightly narrowed. Nearing the Red Gate Palace, both sides of the buildings are closer, and where Feiyun Pavilion stands at the moment, the spatial sequence reaches a climax along with the sentiments of the visitors. After entering the door, the light darkens, the mouth of the cave is suddenly opened, and the visitors' emotions return to calmness. The whole spatial sequence that alternates between light and darkness, as well as between open and bundled adds to the fascination of sightseeing (Figure 10.).

\subsection{Characteristics of the courtyard space}

\subsubsection{Reasonable and ingenious overall layout}

The layout is compact and reasonable, the space twists and turns, and the steps effectively eliminate the height difference as well as connect the courtyard space. Each courtyard is spread along the axis, but the layout is not strictly symmetrical which not only respects the spatial order of traditional buildings, but it also well reflects the spatial characteristics of mountain buildings ${ }^{[12]}$.

\subsubsection{Rich and well-proportioned space}

Along the central axis, the buildings alternate from single or double buildings to three or even grouped buildings, and finally return to a single building. On the plane, it is simple - complex - simple, while the external space presents a passive - positive - negative transition. The contrast between the large and the 
small, freedom and strict, open and closed courtyard acquires rhythm. The plane composition is clear and simple. The sense of place of the palace can be interpreted through rich spatial sequences ${ }^{[12]}$.

\subsubsection{Friendly and pleasant spatial scale}

The small area of the core space courtyard marks the main building which is not very large but appears majestic and solemn. The vision of the transition space and the subsequent space is relatively wide which is in contrast with the core space courtyard. This kind of space pattern which conforms to topography, breaks the traditional pattern, and in combination with the volume of the building which is close to the folk house, gives out a friendly and pleasant feeling.

\section{Conclusion}

The Red Gate Palace, an ancient architectural complex, is to the east of the river, the west of Dacang Ridge, and there are hiking trails in the mountain. Based on these circumstances, it appears to be organic. Relying on the unique natural landscape and cultural environment of Mount Tai, the combination of Yuanjun, in the west and Maitreya, in the east explains the integration and development of Taoism and Buddhism in Mount Tai which carries rich historical and religious cultural values. Through rich spatial transformation and careful line of sight arrangement, the contradiction of the courtyard expansion scale demands and the limitations by mountainous terrain is resolved in which a unique mountain palace landscape is formed.

\section{Disclosure statement}

The author declares no conflict of interest.

\section{References}

[1] Qu J, 2005, Taishan Tongjian, Qilu Publishing House, Jinan.

[2] Ma M, Yan C, 1992, Daishi Annotated, Qingdao Ocean University Press, Qingdao.

[3] (Qing Dynasty) Zhu X, 1774, Taishan Disposition, [Publisher unknown] (photocopy).

[4] (Qing Dynasty) Nie J, 1987, Mount Taishan, Shandong Friendship Publishing House, Ji'nan.

[5] (Ming Dynasty) Wang Z, Zhou Y, 2006, Mount Tai Records Proofread, Huangshan Publishing House, Hefei.

[6] Li H, 2014, Study on the Environment and Space of Taoist Temples in Wudang Mountain, Beijing Forestry University, Beijing.

[7] Qiu J, Ke X, 2015, Viewing the Thought of Nature View from the Space Form of Chinese Traditional Courtyard. Architecture and Culture, (12): 90-92.

[8] Yoshini A, 1985, External Space Design [Yin P, trans.], China Architecture and Building Press, Beijing.

[9] Zhu J, Shen C, Chai M, 2012, Square Scale and Spatial Quality: A Virtual Study of the Relationship between Square Area, Aspect Ratio, Spatial Preference and Imagery. Chinese Landscape Architecture, 28(10): 93-97.

[10] Xu L, Liu N, Sun C, 2012, A Virtual Study on the Relationship between Square Area, Height-Width Ratio, Spatial Preference and Image. Journal of Architecture, (02): 74-78.

[11] Peng Y, 1986, Analysis of Chinese Classical Gardens, China Architecture and Building Press, Beijing.

[12] Min J, 2016, A Study on the Discourse of "Space" in Modern Chinese Architecture from the 1920s to the 1980s, China Architecture and Building Press, Beijing. 